\begin{tabular}{rr} 
çağdaş & Yaratıcı Drama Dergisi 2015, 10(1), 51-62 \\
drama & www.yader.org \\
\hline
\end{tabular}

\title{
İlköğretim Matematik Öğretmenlerinin Matematik Derslerinde Yaratıcı Drama Yönteminin Kullanılmasına Karşı Bakışlarının İncelenmesi
}

\author{
Baki Şahin ${ }^{1}$
}

\begin{tabular}{|c|c|}
\hline Makale Bilgisi & $\ddot{\mathrm{O} z}$ \\
\hline DOI: $10.21612 /$ yader.2015.005 & Bu araştırma, ilköğretim matematik öğretmenlerinin matematik derslerinde \\
\hline $\begin{array}{l}\text { Anahtar Sözcükler } \\
\text { Matematik dersi } \\
\text { Yaratıcı drama yöntemi } \\
\text { İlkögretim matematik } \\
\text { ögretmeni }\end{array}$ & 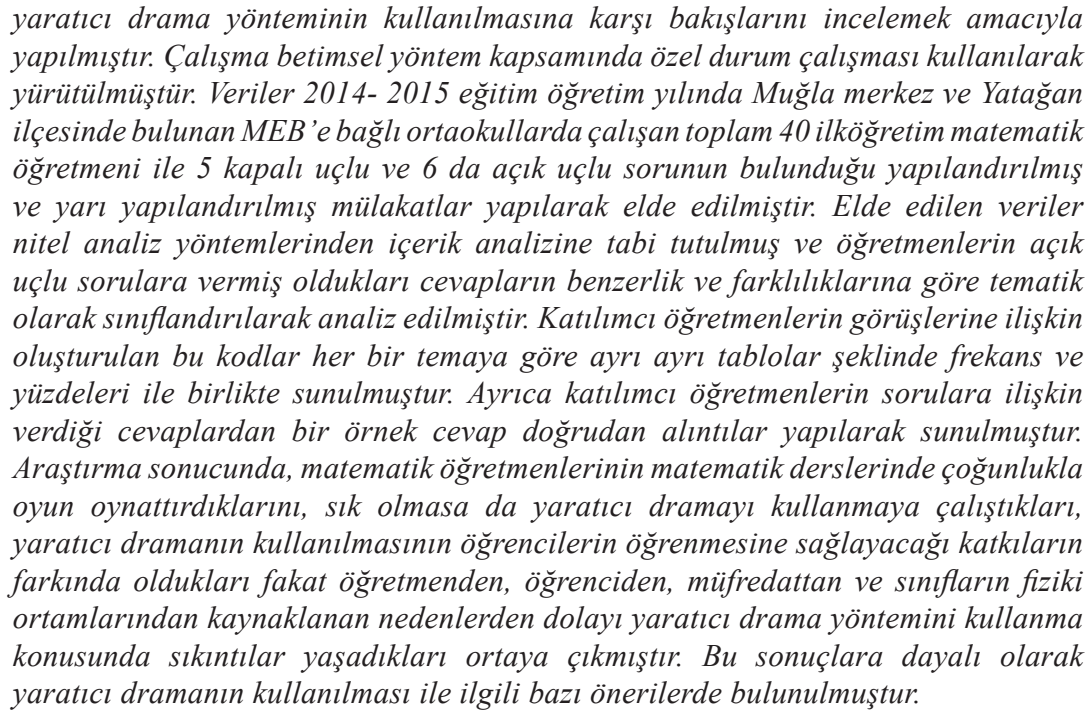 \\
\hline
\end{tabular}

\section{Investigation of Perspective Elementary Mathematics Teacher Against The Use of Creative Drama Method in Maths Course}

\begin{tabular}{|c|c|}
\hline Article Info & Abstract \\
\hline DOI: $10.21612 /$ yader.2015.005 & The aim of this study is to investigation of perspective elementary mathematics \\
\hline $\begin{array}{l}\text { Keywords } \\
\text { Math's courses } \\
\text { Creative drama method } \\
\text { Elementary mathematic's } \\
\text { teacher }\end{array}$ & $\begin{array}{l}\text { teacher against the use of creative drama method in math's course. The study is } \\
\text { a descriptive research and case study method was used in this study. Data were } \\
\text { gathered from } 40 \text { elementary mathematics teachers working in Mugla at 2014- } \\
2015 \text { academic years through semi-structured interviews with the participants. } \\
\text { The collected data were subject to content analysis and teachers' answers for the } \\
\text { open-ended questions were grouped thematically according to similarities and } \\
\text { dissimilarities of answers. The created codes related to the participant teachers } \\
\text { opinions were presented separately according to each theme as the form of tables } \\
\text { together with frequency and percentage. In addition, a sample from the responses to } \\
\text { questions regarding the participant teachers was presented with direct quotations. } \\
\text { In conclusion, it is emerged that primary school teachers try to use creative drama in } \\
\text { math's courses but not often. As well as, they are aware of its contribution to students } \\
\text { learning but they have difficulties with using creative drama method in consequence } \\
\text { of students, teaching program and physical environment to classes. Based on these } \\
\text { results, some suggestions were made regarding the use of creative drama. }\end{array}$ \\
\hline
\end{tabular}

1 Yrd.Doç.Dr., Muğla Sıtkı Koçman Üniversitesi Eğitim Fakültesi İlköğretim Matematik Öğretmenliği Anabilim Dalı, E-posta: baki@mu.edu.tr 


\section{Giriş}

Matematik öğretmeninin en büyük sıkıntısı, öğrenciler tarafından matematik derslerinin zor bir ders olarak algılanmasıdır. Öğrenciler genelde matematik dersinden korkarlar. Matematik dersinden yüksek notu zeki olan kişiler alabilir, diye düşünürler. Matematik dersine karşı olan bu alg1, hem matematiğin yapısından hem de matematik öğretiminde kullanılan yöntemlerden kaynaklanmaktadır. Matematik konularının öğretiminde kullanılan yöntemler, soyut bir ders olan matematiği somutlaştıramamakta, bu da öğrencilerin derse karşı ilgilerini ve dikkatlerini dağıtmaktadır.

Öğrenciler aktif olarak katıldıkları, hayatlarıyla ilişkilendirebildikleri ölçüde bir derse ilgi duyar. Bu da öğretmenin kullanacağı yöntemle mümkün olabilir. Öğrenciler, aktif bir şekilde matematiğin içine girerek onu yaşamazlarsa matematiğin ne kadar heyecan verici olduğunu da anlayamazlar. Onların gözünde matematiğin değeri düşer (Dolan, Williamson, Muri, 1997).

Matematik derslerini öğrencinin de aktif olarak katıldığı eğlenceli ve anlaşılır hale getirmek, matematik başarısını arttırmak, matematiğe karşı tutumları olumlu hale getirmek için farklı öğretim yöntem ve teknikleri geliştirilmekte, öğretmenlerin kullanımına sunulmaktadır. Yaratıcı drama da matematik öğretiminde öğrenciyi aktif kılacak, son yıllarda üzerinde çalışmaların yapıldığı bir yöntemdir. Drama yönteminin matematik derslerindeki başarıya ve tutuma olan etkisinin araştırıldığı çalışmalarda drama yönteminin başarıyı ve tutumu anlamlı derecede arttırdı̆̆ görülmüştür (Sözer, 2006; Duatepe ve Akkuş, 2006; Soner, 2005; Ceylan, ,2014). Drama öğrenciyi derste aktif tutan bir yöntemdir. Henkel (2002)'e göre ise yaratıcı drama, öğrencilerin zevk aldıkları, aktif katılım firsatı buldukları bir yöntem olup öğrencilerin fikirlerini serbestçe ifade ederek yaratıcı düşüncelerinin geliştirilmesinde etkili bir rol oynamaktadır.

Öğrenciler matematik derslerinde matematik işlemlerini yapamamak ve problemleri çözememekten dolayı kaygı duyarlar. Problemleri anlamak ve hangi işlemleri yaparak problemi çözeceği öğrenci için önemli bir sorundur. Şenol (2011), yaratıcı drama uygulamalarının ilköğretim ikinci kademe öğrencilerinin problem çözme strateji kullanımları üzerinde etkisini araştırdığ1 çalışmasında; yaratıcı dramanın öğrencilerin kaygılarını azalttı̆ğ, kendini ifade etme becerisini ise arttırdığ şeklinde ifade etmektedir. Öğrenci, kendisine sorulan bir matematik probleminin genelde dışında kalır. Ardı ardına çözülen problemler ve tüketilen sorular onlar için ders dışında anlamsız hale gelmekte, matematiği yaşamdan uzaklaştırmaktadır. Yaratıcı drama öğrencileri problemin odağına alarak, problemleri yaşayarak çözmelerini sağlar. Bu da hayatla ilişkili öğrenmelere neden olur.

Matematiğin öğrenilme sürecinde orkestra şefi konumundaki öğretmenlere önemli roller düşmektedir. Onların kullandıkları yöntem ve teknikler öğrencinin matematiği öğrenmesine ve matematiğe karşı olumlu tutum geliştirmesine neden olacaktır. Taş (2008), 298 sınıf öğretmeniyle yaptığ çalışmada sınıf öğretmenlerinin drama yönteminin öğrencilerin matematik dersindeki temel becerileri öğrenmelerine katkıda bulunduğunu belirtmiştir. Öğretmenlerin drama konusundaki eğitimleri, drama yöntemine karşı tutumları bu yöntemi derslerinde kullanmalarına önemli katk1 sağlayacaktır. Ancak drama yönteminin kullanılmasının diğer yöntemlerden farklı olarak bazı gereksinimleri olmaktadır. Bu gereksinimler olmayınca yöntemin kullanımında da aksaklılar olabilir. Yıldız (2011) yaptığı çalışmada matematik öğretmenlerinin yaratıcı dramayı matematik derslerinde kullanırken karşılaştıkları sorunları; mekânların dramaya uygun olmaması, matematik öğretim programında dramaya uygun kazanımların yetersizliği, drama alanında yapılan çalışmaların azlığı, 
matematik ve drama kaynaklarının azlığı, kaynaklara ulaşmada yaşanan sıkıntılar olarak belirttiklerini söylemektedir. Aykaç ve Köğce (2014) de sınıf öğretmenleri ile yaptıkları çalışmalarında sınıf öğretmenlerinin matematik derslerinde çok sık olmasa da yaratıcı dramayı kullanmaya çalıştıklarını, yaratıcı dramanın kullanılmasının öğrencilerin öğrenmesine sağlayacağı katkıların farkında oldukları fakat öğretmenden, öğrenciden, müfredattan ve sınıfların fiziki ortamlarından kaynaklanan nedenlerden dolayı yaratıcı drama yöntemini kullanma konusunda sıkıntılar yaşadıklarını belirtmişlerdir. Bu çalışmada da ilköğretim matematik öğretmenlerinin yaratıcı drama konusundaki altyapılarını, yaratıcı dramaya karşı bakışlarını belirlemek amaçlanmıştır.

\section{Yöntem}

$\mathrm{Bu}$ araştırma nicel ve nitel verilerin kullanıldığı betimsel bir araştırmadır. Muğla il merkezi ve Yatağan ilçesinde görev yapmakta olan ilköğretim matematik öğretmenlerinin yaratıcı drama bilgileri, ilgileri ve derslerinde yaratıcı drama yöntemini kullanma durumları hakkındaki görüş ve düşüncelerini belirlemek amacıyla yapılan bütüncül tek durum deseninin kullanıldığı bir durum çalışmasıdır. Durum çalışmaları, bir sınıf, bir mahalle, bir örgüt gibi doğal bir çevre içinde gerçekleştirilir ve çalışmaya konu olan ortam veya olayların bütüncül bir yorumunu hedefler (Yıldırım ve Şimşek, 2005).

\section{Çalışma Grubu}

$\mathrm{Bu}$ çalışma Muğla il merkezi ile ona en yakın ilçelerinden olan Yatağanda 14 farklı ortaokulda, 26 farklı üniversiteden mezun 40 matematik öğretmeni ile yürütülmüştür. Çalışma evreni 51 öğretmenden oluşmaktadır. Bu öğretmenlerin 42'sine ulaşılabilmiş, bunlardan bir tanesi verdiği cevapların tutarsız olmasından, diğeri ise ücretli öğretmen olmasından dolayı çalışmaya dâhil edilmemiştir.

Tablo 1. Matematik Öğretmenlerinin Profilleri

\begin{tabular}{|c|c|c|c|c|c|c|c|c|c|c|}
\hline & \multicolumn{2}{|c|}{ Cinsiyet } & \multicolumn{4}{c|}{ Mezun Olduğu Bölüm } & \multicolumn{4}{c|}{ Kıdem } \\
\hline & Erkek & Kadın & IMÖ & MB & MÖ & IFÖ & $\mathbf{0 - 1 0}$ & $\mathbf{1 0 - 2 0}$ & $\mathbf{2 0 - 3 0}$ & $\mathbf{3 0 -}$ \\
\hline $\mathbf{f}$ & 23 & 17 & 14 & 11 & 4 & 1 & 19 & 12 & 2 & 7 \\
\hline $\mathbf{\%}$ & 57,5 & 42,5 & 35 & 27,5 & 10 & 2,5 & 47,5 & 30 & 5 & 17,5 \\
\hline
\end{tabular}

Tablo 1 de görüldüğü gibi öğretmenlerin \%57,5 ini erkek, \%42,5 ini ise kadın öğretmenler oluşturmaktadır. Öğretmenlerin yalnızca $\% 35$ i ilköğretim matematik öğretmenliği bölümü mezunudur. Mezun oldukları diğer bölümler \%27,5 matematik bölümü, \%10 matematik öğretmenliği, $\% 2,5$ de ilköğretim fen bilgisidir.

\section{Verilerin Toplanması ve Analizi}

Veriler 5 kapalı uçlu seçmeli, 7 kapalı uçlu sorudan oluşmaktadır. Kapalı uçlu sorular kişisel bilgilerin de yer aldığı anket formundan öğretmenlere verilmiş, daha sonra yarı yapılandırılmış açık uçlu sorulardan oluşan görüşme formu soruları öğretmenlere sorulmuştur. Görüşme formu soruları öğretmenlerin dramayı derslerinde yöntem olarak kullandıkları düşüncesiyle iki alan uzmanının da görüşü alınarak hazırlanmıştır.

Görüşme formu, derslerinde drama dersini kullandığını belirten 20 öğretmene uygulanmıştır. Uygulama öncesinde öğretmenlere sorular verilmiş, incelemeleri istenmiştir. Daha sonra öğretmenlere 
sorular yöneltilerek sorulara verdikleri cevaplar not alınarak kaydedilmiştir. Görüşmeler bireysel olarak genelde öğretmenler odası ya da okulun kantininde yapılmış. Ortalama 15 dakika sürmüştür. Cevaplar not edilerek kaydedilmiştir.

Görüşme formunda yer alan sorulara verilen yanıtlar araştırmacı tarafından benzerliklerine ve farklılıklarına göre kodlanarak ortak kodlar ve temalar oluşturulmuştur (Merriam, 1988; Yin, 1994). Uzman görüşlerine başvurularak bu kod ve temalara son hali verilmiştir. Analiz sürecinde izlenen bu yol çalışmanın güvenirliğini artırmak, kodlamaları ve temaları gözden geçirip doğrulamak için gerekli ve önemli bir süreçtir. Oluşturulan bu kodlar ve temalar tablolaştırılıp, frekans ve yüzde değerleri ile birlikte ve her bir koda ilişkin bir örnek öğretmen cevabı doğrudan alıntılar yapılarak sunulmuştur. Alıntılarda öğretmenler (Ö numara) şeklinde kodlanmıştır.

\section{Bulgular}

$\mathrm{Bu}$ bölümde, matematik öğretmenlerinin yaratıcı drama ile ilgili ön bilgileri ve matematik derslerinde yaratıcı dramanın kullanılması ile ilgili görüşlerinden elde edilen kod ve temalara ilişkin bulgular sunulmuştur. Çalışmaya katılan öğretmenlerin "yaratıcı drama" bilgi düzeyleri ile yaratıcı drama İle İlgili bir eğitime katılıp katılmadıklarını gösteren bilgiler aşağıdaki tabloda sunulmuştur.

Tablo 2. Öğretmenlerin "Yaratıcı Drama” Bilgi Düzeyleri ile Yaratıcı Drama İle İlgili Ĕgitime Katılma Durumlarını Gösteren ikili Karşılaştırmalar

\begin{tabular}{|ll|c|c|c|}
\hline & & \multicolumn{2}{|c|}{$\begin{array}{l}\text { Yaratıcı Drama ile ilgili bir eğitim programına } \\
\text { katıldınız mı? }\end{array}$} & \\
\cline { 3 - 4 } & & Evet & Hayır & Toplam \\
\hline \multirow{2}{*}{$\begin{array}{ll}\text { Bir öğretim yöntemi } \\
\text { olarak "Yaratıcı }\end{array}$} & Cok iyi & 1 & 1 & 2 \\
Drama" konusundaki & Òyi & 5 & 6 & 11 \\
bilginiz nasıldır? & Kötü & 3 & 15 & 18 \\
& Hic bilgim yok & 0 & 5 & 5 \\
& & 0 & 4 & 4 \\
& Toplam & 9 & 31 & 40 \\
\hline
\end{tabular}

Tablo 2'ye göre 31 (\%78) öğretmen drama ile ilgili bir eğitim programına katılmadıklarını söylemişlerdir. Yaratıcı drama bilgisini "Çok iyi” olarak söyleyen 2 öğretmenden biri drama eğitimi aldığını söylemiştir. Görüşme sırasında nasıl bir eğitim aldığı sorulduğunda, Çağdaş Drama Derneği’nin Liderlik Eğitimi Programına katıldığını ve 5. Aşamayı bitirdiğini belirtmiştir. Diğer öğretmen ise herhangi bir eğitim almadığını, okuyarak yaratıcı dramayı öğrendiğini belirtmiştir. Yaratıcı drama bilgisini "İyi” olarak söyleyen öğretmenlerden de 6 tanesi (\%15), "orta" olarak söyleyenlerden de 15 tanesi (\%38) herhangi bir eğitim almadıklarını söylemektedirler. Matematik öğretmenleri bu bilgi seviyelerini okuyarak ve izleyerek oluşturduklarını söyleyerek bir bakıma bunun için herhangi bir eğitime de gerek yok algısını oluşturmaktadır. Öğretmenlere drama eğitimi ile ilgili bir eğitime katılmayı düşünseler nasıl bir eğitim istedikleri sorulmuş, verdikleri cevaplar Tablo 3 de sunulmuştur. 
Tablo 3. Matematik Öğretmenlerinin "Drama ile ilgili bir eğitime katılmayı düşünseniz nasıl bir eğitime katılırdınız?” Sorusuna Verdikleri Yanıtlar

\begin{tabular}{|r|c|c|}
\hline & Frekans & \% \\
\hline Hizmet İçi Eğitim Kursu & 16 & 40 \\
İl/İlçe Milli Eğitimin Düzenlediği Bir Kurs & 6 & 15 \\
Proje(Tübitak/GEKA gibi) & 20 & 50 \\
Özel Bir Kurs & 5 & 12,5 \\
Hiçbiri & 1 & 2,5 \\
\hline
\end{tabular}

Öğretmenlere birden fazla seçim yapabilecekleri söylendiğinden yüzdeler toplamı 100 olmamıştır.

Tablo 3'den de görüleceği gibi bir öğretmen hariç tüm öğretmenler drama konusunda bir eğitim alma konusunda istekli görünüyor. Ağırlıklı olarak Proje kapsamında bir eğitim almak istemektedirler (\%50). Hizmet içi eğitim kursu (\%40), İl/İlçe milli eğitimin düzenlediği bir kurs $(\% 15)$ ve özel bir kurs $(\% 12,5)$ istek sırasını oluşturmuştur. Proje kapsamında isteklilerin sayısının fazla olması, kısa bir süre önce bu öğretmenlerin matematik eğitimiyle ilgili üniversitede bir eğitim almış olmaları ile açıklanabilir. Her ne şekilde olursa olsun matematik öğretmenlerinin drama konusunda eğitim almak istiyor olmaları, bu öğretmenlerin derslerinde bir yöntem olarak yaratıcı dramayı kullanmak istiyor olmaları şeklinde de yorumlanabilir.

Matematik öğretmenlerine “Derslerinizde en çok kullandığınız öğretim yöntem(ler)i nedir?" sorusu sorulmuş, elde edilen bulgular tablo 4’te verilmiştir.

Tablo 4. Öğretmenlerin "Derslerinizde en çok kullandiğınız öğretim yöntem(ler)i nedir?" Sorusuna Verdikleri Yanitlar

\begin{tabular}{|r|c|c|}
\hline & Frekans & $\mathbf{\%}$ \\
\hline Anlatım & 34 & 85 \\
Tartışma & 25 & 62,5 \\
Örnek Olay & 21 & 52,5 \\
Gösterip Yaptırma & 35 & 87,5 \\
Problem Çözme & 37 & 92,5 \\
Bireysel Çalışma & 18 & 45 \\
Yaratıcı Drama & 5 & 17,5 \\
\hline
\end{tabular}

Tablo 4 incelendiğinde matematik öğretmenlerinin kullandıkları yöntemler içinde yaratıcı dramanın çok az yer $(\% 17,5)$ tuttuğu görülebilmektedir. Bunun nedeni Tablo 5'te verilecek olan öğretmenlerle yapılan görüşme analizlerinde görülebilir. 
Tablo 5. Matematik Öğretmenlerinin "İlkögrretim matematik derslerinde Yaratıcı Drama Yönteminin matematik ögretiminde kullanılabilecek etkili bir yöntem olduğunu düşünüyor musunuz?" Sorusuna Verdikleri Yanitlar

\begin{tabular}{|r|c|c|}
\hline & Frekans & \% \\
\hline Kesinlikle evet & 7 & 17,5 \\
Evet & 22 & 55 \\
Hayır & 4 & 10 \\
Fikrim Yok & 7 & 17,5 \\
Toplam & 40 & 100 \\
\hline
\end{tabular}

Matematik öğretmenlerine "Yaratıcı drama yönteminin matematik dersi için ilköğretimin kaçıncı sınıflarında uygulanmasının uygun olduğunu düşünüyorsunuz?" sorusuna verdikleri yanıtlar tablo 6 da sunulmuştur.

Tablo 6. Matematik Öğretmenlerine Göre Derslerinde Yöntem Olarak Yaratıcı Dramanın Kullanılmasının Uygun Olduğu Sinıf Düzeyleri

\begin{tabular}{|c|c|c|c|}
\hline Kod No & Kodlar & f & $\%$ \\
\hline 1 & $1-3$ & 4 & 29 \\
\hline 2 & 4 & 11 & 79 \\
\hline 3 & 5 & 13 & 93 \\
\hline 4 & 6 & 6 & 43 \\
\hline 5 & $7-8$ & 5 & 35 \\
\hline \multicolumn{4}{|c|}{ Her kodla ilgili bir öğretmen görüsü } \\
\hline 1 & \multicolumn{3}{|c|}{ Bu sınıflar dokunarak, yaşayarak öğrenir. (ö17) } \\
\hline 2 & \multicolumn{3}{|c|}{... küçük sınıfların drama ya karşı daha ilgili olacaklarını düşünüyorum.(ö33) } \\
\hline 3 & \multicolumn{3}{|c|}{$\begin{array}{l}\text {...daha küçük sınıflarda öğrencilerin hazır bulunuşluk seviyelerinin yeterli olmadığını } \\
\text { düşünüyorum. 7-8. sınıflarda ise müfredat çok yoğun.(ö31) }\end{array}$} \\
\hline 4 & \multicolumn{3}{|c|}{$\begin{array}{l}\text {... bu sınıflarda uygulaması daha uygun olabilir. 7. sınıftan itibaren öğrenciler soyut düşünmeye } \\
\text { başlıyorlar.(ö36) }\end{array}$} \\
\hline 5 & \multicolumn{3}{|c|}{$\begin{array}{l}\text { her aşamasında kullanılabileceğini düşünüyorum. Çünkü, matematik gibi bir dersi hem } \\
\text { eğlenceli hale getiriyor hem de somutlaştırıyor.(ö2) }\end{array}$} \\
\hline
\end{tabular}

Tablo 6 incelendiğinde öğretmenlerin \% 79'unun 4. sinıflarda, \% 93'ünün de 5. sinıflarda derslerinde yaratıcı dramayı kullanmanın daha uygun olduğunu belirttikleri görülmektedir. Bu sınıflar ilköğretimin ara sınıflarıdır. Öğretmenler bu görüşlerini öğrencilerin hâlâ oyun döneminde olmaları, müfredatın bu sınıflarda yoğun olmaması, yaratıcı dramanın bu sınıfların konularına uygulamanın daha kolay olması gibi gerekçeler belirttikleri görülmüştür.

Matematik öğretmenlerinin "Yaratıcı drama yöntemi kapsamında derslerinizde genellikle hangi çalışmaları/etkinlikleri (oyun oynatarak, doğaçlama ve rol oynatarak, canlandırma vb.) kullanarak yaptırıyorsunuz?" sorusuna verdikleri yanıtlar tablo 7'de sunulmuştur. 
Tablo 7. Matematik Öğretmenlerinin Derslerinde Kullandıkları Yaratıcı Drama Teknikleri

\begin{tabular}{|c|c|c|c|}
\hline Kod No & Kodlar & f & $\%$ \\
\hline 1 & Oyun, doğaçlama, canlandırma & 2 & 14 \\
\hline 2 & Doğaçlama, canlandırma & 3 & 21 \\
\hline 3 & Oyun, canlandirma & 2 & 14 \\
\hline 4 & Oyun & 7 & 50 \\
\hline \multicolumn{4}{|c|}{ Her kodla ilgili bir öğretmen görüsü } \\
\hline 1 & \multicolumn{3}{|c|}{ Derse ısınma amaçlı olarak oyun, ders içinde canlandırma, doğaçlama kullanıyorum.(ö13) } \\
\hline 2 & \multicolumn{3}{|c|}{$\begin{array}{l}\text { Sınıfımızın fiziki şartları ve öğrencilerin hazır bulunuşluklarına daha uygun olduğunu } \\
\text { düşünüyorum.(ö35) }\end{array}$} \\
\hline 3 & \multicolumn{3}{|c|}{ Problem çözümlerinde daha çok kullanıyorum. Problemlerin daha iyi anlaşılması için. (ö36) } \\
\hline 4 & \multicolumn{3}{|c|}{$\begin{array}{l}\text { Oyun çocuk için çok önemli ve çocuklar oyun oynarken bir yandan da matematiğin konularını } \\
\text { kalıcı bir şekilde öğreniyorlar.(ö2) }\end{array}$} \\
\hline
\end{tabular}

Tablo 7 incelendiğinde öğretmenlerin derslerinde en çok (\%50) oyun oynama tekniğini kullandıkları, bunun nedenini de öğrencilerin oyun oynarken eğlendikleri, derse ilgilerinin arttığ1, öğrenmenin kalıcı hale gelmesini sağladıkları şeklinde belirtmişlerdir. Doğaçlama ve canlandırmayı bir problemi anlamak için kullandıklarını, bu tekniklerin öğrencilerin hazır bulunuşluk düzeylerine uygun olan teknikler olduğunu söylemişlerdir.

$\mathrm{Bu}$ cevaplardan da anlaşıldığ gibi öğretmenler yaratıcı drama bilgisine yeterince hakim değildirler. Bu soruda örnek olarak verilen canlandırma, doğaçlama ve oyun oynama teknikleri haricinde tekniklerden haberdar olmadıkları görülmektedir. Öğretmenlerin büyük çoğunluğu yaratıcı dramayı oyun oynama şeklinde algılamaktadır.

Matematik öğretmenlerinin "Yaratıcı drama yönteminin matematik derslerinde uygulanmasında karşılaştığınız sorunlar (sınıf mevcudunun ve mekânın uygun olmaması, drama yöntemini kullanmadaki yetersizlik, öğrencilerin bu etkinliklere katılımdaki yetersizlikler) nelerdir?" sorusuna verdikleri yanıtlar tablo 8'de sunulmuştur.

Tablo 8. Matematik Öğretmenlerinin Derslerinde Yaratıcı Drama Yöntemini Kullanırken Karşılaştıkları Zorluklar

\begin{tabular}{|c|l|c|c|}
\hline Kod No & Kodlar & f & \% \\
\hline 1 & Mekân & 5 & 36 \\
\hline 2 & Zaman yetersizliği & 2 & 14 \\
\hline 3 & Öğrenci katılımının yetersiz olması & 3 & 21 \\
\hline 4 & Kaynak sıkıntısı & 2 & 14 \\
\hline 5 & Sinıfların kalabalık olması & 4 & 29 \\
\hline 6 & Müfredat yoğunluğu & 2 & 14 \\
\hline
\end{tabular}




\begin{tabular}{|c|c|}
\hline \multicolumn{2}{|r|}{ Her kodla ilgili bir öğretmen görüsü } \\
\hline 1 & Sınıfların küçük olması, boş oyun alanının olmamasından dolayı zorluklar yaşanıyor.(ö36) \\
\hline 2 & $\begin{array}{l}\text { Yaratıcı drama oyunlarının matematik terimleri, sembolleri ve konularıyla ilişkilendirilmesi } \\
\text { gerekiyor. Bu planlama çok zaman alıyor.(ö13) }\end{array}$ \\
\hline 3 & $\begin{array}{l}\text { Öğrenci katılımındaki yetersizlikler ve uygulama sırasında öğrencilerden dönütlerin istenilen } \\
\text { düzeyde olmaması, sınıf hakimiyetinin dağılması açısından sorunlar yaşıyorum.(ö35) }\end{array}$ \\
\hline 4 & ... derslerin planlanmasında özellikle zaman açısından zorluklarla karşılaşıyorum.(ö3) \\
\hline 5 & $\begin{array}{l}\text { Sınıf mevcutları çok kalabalık. Bu da yaratıcı drama yönteminin uygulanmasında her öğrenciye } \\
\text { ulaşamama sorununa sebep oluyor.(ö31) }\end{array}$ \\
\hline 6 & Müfredat çok yoğun olduğundan dolayı yaratıcı dramayı her zaman kullanamıyorum.(ö2) \\
\hline
\end{tabular}

Tablo 8 incelendiğinde öğretmenlerin derslerinde yaratıcı drama yöntemini kullanırken karşılaştıkları sorunlar şu şekilde sıralanmaktadır: \%36 mekân, \%29 sınıfların kalabalık olması, \%21 öğrenci katılımının yetersiz olması, \%14 zaman yetersizliği, \%14 kaynak sıkıntısı, \%14 müfredat yoğunluğu. Öğretmenler okullarında sınıfları haricinde drama yapılacak uygun koşulları olan bir mekânlarının olmadığını, bunun da yaratıcı drama yöntemini kullanmayı kısıtladığını belirtmişlerdir. Sınıfların kalabalık olması öğretmenlerin ikinci sorunu olarak karşımıza çıkmaktadır. Öğretmenler, kalabalık sınıflarda yaratıcı drama yönteminin kullanımının öğrenciye ulaşılmayı engellediğini söylemektedirler. Özellikle üst sınıflarda öğrencilerin derse katılmasını sağlamakta sorunlar yaşadıklarını söyleyen öğretmenler, öğrencileri konuşturmak ve etkinliklere katmanın zor olduğunu belirtmişlerdir. Öğretmenler özellikle konuya uygun drama etkinliği bulma konusunda sıkıntı yaşadıklarını belirtirken, etkinlik yazmanın hem çok zaman aldığını hem de uygun etkinlik yazma konusunda yetersiz olduklarını söylemişlerdir. TEOG sınavına hazırlanan 7 ve 8 . sınıf öğrencileri için yaratıcı drama yöntemini kullanmayı tercih etmedikleri söyleyen öğretmenler, "zaten bu sınıfların müfredatları çok yoğun, bu da yaratıcı dramayı kullanmayı engellemektedir” demişlerdir.

Matematik öğretmenlerinin "Yaratıcı drama yöntemini dersinizde uygulama konusunda kendinizi yeterli hissediyor musunuz?” sorusuna verdikleri yanıtlar Tablo 9'da sunulmuştur.

Tablo 9. Matematik Öğretmenlerinin Yaratıcı Drama Konusunda Kendilerini Algılayışları

\begin{tabular}{|c|c|c|c|}
\hline Kod No & Kodlar & f & $\%$ \\
\hline 1 & Yeterli hissetmiyorum & 11 & 79 \\
\hline 2 & Kismen yeterli hissediyorum & 2 & 14 \\
\hline 3 & Yeterliyim & 1 & 7 \\
\hline \multicolumn{4}{|c|}{ Her kodla ilgili bir öğretmen görüşü } \\
\hline 1 & \multicolumn{3}{|c|}{ Çok yeterli değilim çünkü bu konuda hiç eğitim almadım. (ö33) } \\
\hline 2 & \multicolumn{3}{|c|}{ Elimde dokümanlar olsa planlama yaparak uygulayabileceğimi düşünüyorum. (ö30) } \\
\hline 3 & \multicolumn{3}{|c|}{$\begin{array}{l}\text { Kendimi yeterli hissediyorum çünkü gerçekten bu konuyu çok araştırıyorum, eğitimini aldım. } \\
\text { (ö2) }\end{array}$} \\
\hline
\end{tabular}


Tablo 9 incelendiğinde öğretmenlerin \%79'unun yaratıcı dramayı derslerinde kullanma konusunda yeterli hissetmedikleri görülmektedir. Bunun da temel nedenini eğitim almamış olmalarına bağlamaktadırlar. Bir başka nedenin de matematik derslerinde yaratıcı dramayı kullanacakları yeterli dokümanın olmaması şeklinde ifade etmektedirler.

Matematik öğretmenlerinin "Yaratıcı drama yönteminin matematik derslerinde nas1l kullanılacağıyla ilgili hizmet içi eğitim aldınız mı? Ne zaman ve nasıl bir eğitim aldınız? Eğer almadıysanız bu yöntemi kullanma ile ilgili eğitim almayı düşünüyor musun?" sorusuna verdikleri yanıtlar tablo 10 da sunulmuştur.

Tablo 10. Matematik Öğretmenlerinin Yaratıcı Drama ile İlgili Ĕgitim Durumları

\begin{tabular}{|l|l|l|l|}
\hline Kod No & Kodlar & $\mathrm{f}$ & $\%$ \\
\hline 1 & Eğitim aldım & 4 & 29 \\
\hline 2 & Almadım & 10 & 71 \\
\hline \multicolumn{1}{|c|}{ Her kodla ilgili bir öğretmen görüsü } \\
\hline 1 & $\begin{array}{l}\text { "Öğretmen Akademisi Vakfının” düzenlediği “Öğrenen Öğretmen” adlı bir eğitime katılmıştım. } \\
\text { (ö31) }\end{array}$ & \\
\hline 2 & Ĕ̆itim almadım ama uygun bir eğitim açılırsa katılmak isterim. (ö33) \\
\hline
\end{tabular}

Tablo 10'da da görüleceği gibi öğretmenlerimizin \%71'i drama konusunda herhangi bir eğitim almadıklarını söylemektedirler. Drama eğitimi almayan bu öğretmenlerin hepsi yaratıcı drama ile ilgi bir eğitime katılacaklarını, bu eğitimin kendileri için faydalı olacağını belirtmektedirler. Eğitim aldığını söyleyen 3 öğretmenden 1 tanesi "Çağdaş Drama Derneği”nin "Yaratıcı Drama Liderlik Programı”nı tamamladığını ve dört yıldır dramanın içinde olduğunu söylerken, bir diğer katılımcı üniversite yıllarında seçmeli drama dersi aldığını, diğer katılımcı ise hizmet içi eğitimde drama kursuna katıldığını söylemişlerdir. Bu tablodan da görüleceği gibi öğretmenlerimizin yaratıcı drama konusunda eğitimlerinin olmadığı ancak eğitime açık oldukları görülmektedir.

Matematik öğretmenlerinin "Yaratıcı drama yöntemini matematiğin en çok hangi konularında kullanıyorsunuz?” sorusuna verdikleri yanıtlar Tablo 11'de sunulmuştur.

Tablo 11. Matematik Öğretmenlerinin Derslerinde Yaratıcı Drama Yöntemini Kullandıkları Ögrenme Alanlarl

\begin{tabular}{|c|l|c|c|}
\hline Kod No & Kodlar & f & \% \\
\hline 1 & Tüm Öğrenme Alanları & 1 & 7 \\
\hline 2 & Sayılar & 6 & 43 \\
\hline 3 & Ölçüler & 2 & 14 \\
\hline 4 & Geometri & 4 & 14 \\
\hline 5 & Problem Çözme & 6 & 29 \\
\hline 6 & Belli Bir Konu Yok & & 43 \\
\hline
\end{tabular}




\begin{tabular}{|c|l|}
\hline \multicolumn{2}{|c|}{ Her kodla ilgili bir öğretmen görüşü } \\
\hline 1 & Yaratıcı drama yöntemini hemen hemen her konuda kullanabilirim. (ö31) \\
\hline 2 & Sayılar arasında karşıllaştırmalar, sıralamalar yaparken kullanıyorum. (ö33) \\
\hline 3 & Uzunluk ölçü birimleri, zaman ölçme kullanıyorum. (ö26) \\
\hline 4 & ... şekilleri öteleme, yansıma, benzerlik, eşlik konularında kullanıyorum. (ö3) \\
\hline 5 & Problem çözerken kullanıyorum. (ö31) \\
\hline 6 & Kavram ve sembollerin tanıtılmasını oyun ile öğretiyorum. (ö13) \\
\hline
\end{tabular}

Tablo 11 incelendiğinde öğretmenlerin \%43'ünün belli bir konu belirtmediklerini görülür. Bu öğretmenler çok nadir olarak bazen oyun oynattıklarını, dolayısıyla drama yöntemini kullandıklarını düşünmektedirler. Yine öğretmenlerin \%43’ü sayılar öğrenme alanındaki konularda yaratıcı dramay1 kullandıklarını belirtmişlerdir. Bu öğretmenlerin de sayılarla ilgili oyun etkinlikleri yaptırdıklarını açıklamalarından anlamaktayız. Öğretmenlerimiz etkinlikleriyle ilgili verdikleri örneklerde Tablo 9'da da belirttikleri gibi yaratıcı drama konusunda yetersiz olduklarını, ama bildikleri bazı oyunları konulara bütünleştirmek suretiyle etkinlik yaptıklarını açıklamaktadırlar.

Matematik öğretmenlerinin "Yaratıcı drama yönteminin Matematik derslerinde daha etkili bir şekilde uygulanabilmesi için önerileriniz nelerdir?” sorusuna verdikleri yanıtlar tablo 12'de sunulmuştur.

Tablo 12. Matematik Öğretmenlerinin Yaratıcı Drama Yönteminin Matematik derslerinde Kullanılabilmesine Yönelik Önerileri

\begin{tabular}{|c|l|c|c|}
\hline Kod No & \multicolumn{1}{|c|}{ Kodlar } & f & \% \\
\hline $\mathbf{1}$ & Eğitim verilmeli & 10 & 71 \\
\hline $\mathbf{2}$ & Müfredatın yoğunluğu azaltılmalı & 4 & 29 \\
\hline $\mathbf{3}$ & Sinıf mevcutları azaltılmalı & 2 & 14 \\
\hline $\mathbf{4}$ & Drama sınıflarının olmaması & 2 & 14 \\
\hline \multicolumn{3}{|c|}{ Her kodla ilgili bir öğretmen görüsü } \\
\hline $\mathbf{1}$ & Alanında uzman kişilerce konu bazında eğitimler verilebilir. (ö26) \\
\hline $\mathbf{2}$ & Sinıflardaki ders müfredatının yoğunluğu(özellikle 7 ve 8. sınıfların) azaltılmalı...(ö3) \\
\hline $\mathbf{3}$ & .. sinıf mevutları düşürülebilir. (ö31) \\
\hline $\mathbf{4}$ & ... sınıfların drama kullanımına uygun hale getirilmeli. (ö2) \\
\hline
\end{tabular}

Tablo 12 incelendiğinde öğretmenlerin \%71'i yaratıcı drama bilgileri konusunda yetersiz olduklarını vurgulayarak yaratıcı dramayı derslerinde daha etkili kullanabilmeleri için eğitim almaları gerektiğini vurgulamışlardır. Diğer önerilerini \%29 ile müfredat yoğunluğunun azaltılması, \%14 sınıf mevcudunun azaltılması ve \%14 drama sınıflarının oluşturulması şeklinde belirtmişlerdir. Bu sonuçlardan da anlaşılmaktadır ki matematik derslerinde yaratıcı dramanın kullanılabilmesi için eğitim önceliklidir. 


\section{Sonuç ve Öneriler}

Matematik öğretmenlerimiz yaratıcı drama konusunda yeterli düzeyde eğitimli değildirler. Ancak eğitim alma konusunda özellikle genç öğretmenler oldukça istekli olduklarını belirtmişlerdir. Uygun koşullar sağlandığında, alanında uzman kişilerden uygulamalı olarak eğitim almaları durumunda yaratıcı drama yöntemini derslerinde kullanabileceklerini ve bu yöntemin diğer yöntemlerden daha etkili bir öğrenmeyi sağlayacağını düşünmektedirler. Bu bağlamda MEB hizmet içi eğitimlerinde yaratıcı dramayı matematik derslerinde bir yöntem olarak kullanmaya yönelik kurslar açmal1, drama konusunda proje ve seminerlerle de bu desteklenmelidir. Bu durumda, drama konusunda yetişmiş öğretmenlerin, bulundukları okullarda yaratıcı dramanın matematik (ve diğer derslere de öncülük edebilirler) derslerinde kullanılması için gerekli ihtiyaçları bilerek giderme konusunda çalışmalar yapabilecekleri düşünülmektedir.

\section{Kaynakça}

Ceylan, H.(2014) 6. sinıf matematik dersi eşitlik ve denklem konusunun drama yöntemi kullanılarak anlatılmasının ögrenci tutumlarına etkisi. Yayınlanmamış yüksek lisans tezi, Gazi Üniversitesi, Ankara.

Dolan, D. , Williamson, J. , Muri, M. (1997). Mathematics activities for elementary school teachers. USA: Addison-Wesley.

Duatepe, A. ve Akkuş, O. (2006). Yaratıcı dramanın matematik eğitiminde kullanılması: Kümeler alt öğrenme alanında bir uygulama. Yaratıcı Drama Dergisi, 1(1), 32-38.

Henkel, S. A. (2002). Integrated Curriculum, Creative Dramas: Picture the Possibilities. Teaching Elementary Physical Education.

Merriam, S. B. (1988). Case study research in education: A qualitative approach. San Francisco, C.A: Jossey-Bass.

Sözer, N. (2006). Illköğretim 4.sinıf matematik dersinde drama yönteminin öğrencilerin başarılarına tutumlartna ve ögrenmenin kalıcllı̆̆na etkisi. Yayınlanmamış yüksek lisans tezi, Gazi Üniversitesi Eğitim Bilimleri Enstitüsü, Ankara.

Soner. S. (2005). İlköğretim matematik dersi kesikli sayılarda toplama-çıkarma işleminde drama yöntemi ile yapılan ögretimin etkililiği. Yayınlanmamış yüksek lisans tezi, Abant İzzet Baysal Üniversitesi, Bolu.

Şenol, E.N. (2011). İlköğretim matematik dersinde yaratıcı drama uygulamalarının öğrencilerin problem çözme stratejileri başarı benlik kavramı ve etkileşim örüntüleri üzerindeki etkisi. Yayınlanmamış doktora tezi, Dokuz Eylül Üniversitesi, İzmir.

Taş, F.(2008). İlköğretim 1-5. sinıflar matematik dersi temel becerilerine drama tekniğinin katkisına ilişkin ögretmen görüşleri.Yayınlanmamış yüksek lisans tezi, Abant İzzet Baysal Üniversitesi, Bolu.

Yıldız, E. (2011). Yaratıcı dramayı matematik eğitiminde yöntem olarak kullanan öğretmenlerin ve ögretim elemanlarının yönteme ilişkin görüş̧lerinin değerlendirilmesi. Yayınlanmamış yüksek lisans tezi, Ankara Üniversitesi, Ankara.

Yıldırım, A. ve Şimşek, H. (2006). Sosyal bilimlerde nitel araştırma yöntemleri. Ankara: Seçkin Yayıncılık.

Yin, R. K. (1994). Case study research design and methods. (2nd Edition). Thousand Oaks, CA: Sage Publications. 
